\title{
Preparation, Charaterization and Study of Cobalt (II), Nickel (II), Copper (II) and Zinc (II) Complexes of Some Schiff Bases
}

\author{
Zuhoor W. Al-Tuhafy \\ Department of Chemistry / College of Education \\ University of Mosul
}

Received

04 / 05 / 2009
Accepted

05 / 01 / 2010

\section{الخلاصة}

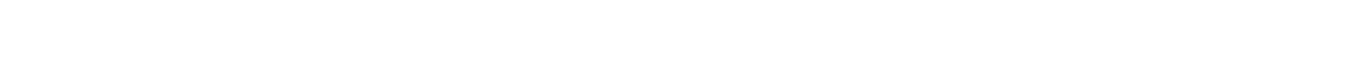
والزكك في حالة الأكسدة الثنائية الموجبة ذوات الصيغة العلمة

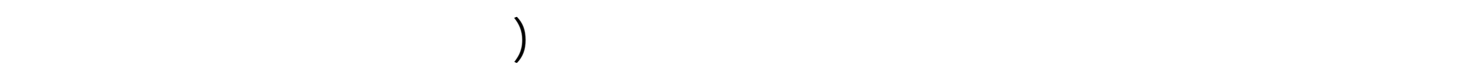

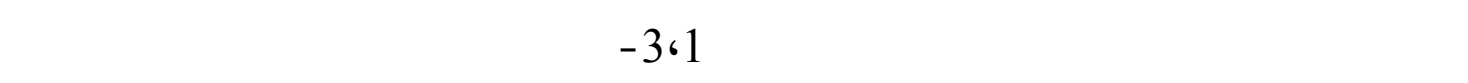

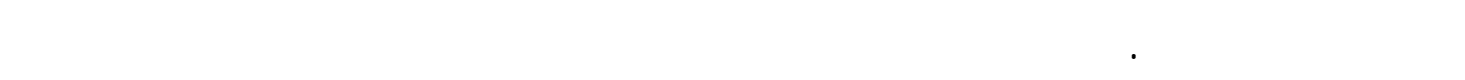

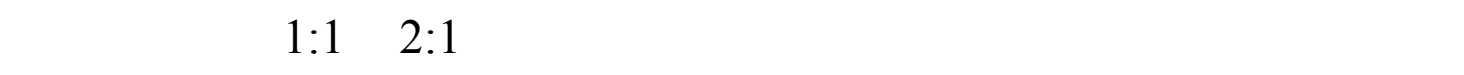
إلى الليكاند، واقترحت بنيت ثماني ورباعي للنطوح لجمبع المعقدات.

\section{ABSTRACT}

Some complexes having the general formula $[\mathrm{ML}] \mathrm{X}_{2},\left[\mathrm{MLX}_{2}\right]$, where $\left(\mathrm{M}=\mathrm{Co}^{+2}, \mathrm{Ni}^{+2}, \mathrm{Cu}^{+2}\right.$ and $\mathrm{Zn}^{+2}, \mathrm{~L}=$ the ligand) obtained by the condensation of o-hydroxy acetophenone with o-amino phenol, ethyl amine and 1,3-propane diamine and $\mathrm{X}=$ chloride ion) where prepared by the reaction of the metal salt with the ligand in ethanolic solution. The complexes have the molar ratio 1:2, 1:1. The complexes were characterized by elemental analysis, molar conductance, infrared and UV. spectral measurements. The studies revealed that the neutral ligands and giving the most expected octahedral and tetrahedral structures for all complexes.

\section{INTRODUCTION}

Schiff bases have been widely used in the field of coordination chemistry[1-5]. The Schiff base complexes have been catalytic reaction 
[6] and as models for biological system [7,8]. The biological activity of Schiff base is attributed to the formation of stable complex with the transition metal present in the cell $[9,10]$ and they are found to exhibt awide variety of pharmacological properties, clinical and analytical [11].

Earlier work was showed that some drugs increased activity when administered as metal chelates rather than as organic compounds and that the coordination possibility of amine has been improved by condensing with variety of carbonyl compounds. In recent years many complexes of Schiff bases were prepared $[12,13]$. This may be attributed to their stability, biological activity[14] and potential applications in many fields such as oxidation catalysis [15], electrochemistry [16], etc. It has been reported that the structure of the substituent bonded to the imino nitrogen affects the coordination geometry of the complexes [17]. Schiff bases with nitrogen and oxygen donor atoms set are well known to coordinate with various metal ions, and this has attracted many authers [18]. This is because of their potential as catalysts for the insertion of oxygen into an organic substrate [19].

In this paper we report the synthesis of a new Schiff base type ligands formed by the condensation of o-hydroxy acetophenone with o-amino phenol, ethyl amine and 1,3-propyl diamine. The ligands system have both nitrogen and oxygen donor sites.

\section{EXPERIMENTAL}

\section{Preparation of the ligands}

The Schiff base ligand HAOP was prepared by reacting equimolar amounts of $o$-hydroxy acetophnone $(0.01 \mathrm{~mol} ; 1.36 \mathrm{~g})$ and $o$-amino phenol $(0.01 \mathrm{~mol} ; 1.09 \mathrm{~g})$ in $40 \mathrm{~cm}^{3}$ ethanol. The reaction mixture was refluxed for about $3 \mathrm{~h}$. The excess solvent was partially evaporated and the resulting product was precipitated by cooling and filtered off, washed with ethanol and dried.

HAEA was prepared from o-hydroxy acetophenone $(0.01 \mathrm{~mol}$; $0.45 \mathrm{~g})$ and ethyl amine $(0.01 \mathrm{~mol}, 0.45 \mathrm{~g})$ whereas HAPA was prepared from o-hydroxy acetophenone $(0.02 \mathrm{~mol} ; 2.72 \mathrm{~g})$ and 1,3-propane diamine $(0.01 \mathrm{~mol} ; 0.74 \mathrm{~g})$ using the above mentioned procedure.

\section{Preparation of complexes}

An ethanolic solution of Schiff bases HAOP, HAEA (0.01 mol) and HAPA $(0.02 \mathrm{~mol})$ was refluxed with $\mathrm{MCl}_{2} \cdot 6 \mathrm{H}_{2} \mathrm{O}$ where $\mathrm{M}=\mathrm{Ni}$ or $\mathrm{Co}$, $\mathrm{CuCl}_{2} \cdot 2 \mathrm{H}_{2} \mathrm{O}, \mathrm{ZnCl}_{2}(0.01 \mathrm{~mol})$ in ethanol for about $3 \mathrm{~h}$. After refluxing the volume of the solution was reduced and the concentrate cooled at room temperature. The solid complex formed was filtered, washed with ethanol and dried. 


\section{Analysis and physical measurements}

The complexes were characterized by elemental analysis and molar conductance in DMF solvent with Lf-42 conductivity bridge. The IR spectra were recorded using the $\mathrm{KBr}$ disc technique (400-4000) $\mathrm{cm}^{-1}$ on a Bruker-Tension 27 spectrophotometer. The electronic spectra in the range 200-1100 nm range were obtained in DMF on a shmadzu UV- $1650 \mathrm{pc}$ spectrophotometer. Magnetic measurements were carried out by faraday method.

\section{RESULTS AND DISCUSSION}

The reactions of metal salts and the Schiff base ligands as follows: $\mathrm{MCl}_{2} \cdot \mathrm{nH}_{2} \mathrm{O}+2 \mathrm{HAOP} \longrightarrow\left[\mathrm{M}(\mathrm{HAOP})_{2}\right] \mathrm{Cl}_{2}+\mathrm{nH}_{2} \mathrm{O} \ldots \ldots \ldots \ldots . . . \mathrm{I}$ $\mathrm{MCl}_{2} \cdot \mathrm{nH}_{2} \mathrm{O}+2 \mathrm{HAEA} \longrightarrow\left[\mathrm{M}(\mathrm{HAEA})_{2}\right] \mathrm{Cl}_{2}+\mathrm{nH}_{2} \mathrm{O} \ldots \ldots \ldots \ldots . . \mathrm{II}$ $\mathrm{MCl}_{2} \cdot \mathrm{nH}_{2} \mathrm{O}+\mathrm{HAPA} \longrightarrow\left[\mathrm{M}(\mathrm{HAPA}) \mathrm{Cl}_{2}\right]+\mathrm{nH}_{2} \mathrm{O} \ldots \ldots \ldots \ldots . . \mathrm{III}$

Where $\mathrm{M}=\mathrm{Co}^{+2}, \mathrm{Ni}^{+2}, \mathrm{Cu}^{+2}$ or $\mathrm{Zn}^{+2}$ $\mathrm{n}=2,6$

The analytical data of the complexes (Table 1) reasonable and agree well will the given formulation. The complexes are stable in air at room temperature.

Conductance in DMF at room temperature indicates 1:2 electrolytes for type I, II complexes but extremely low conductance value of type III complexes suggest their non-electrolytic nature [20].

Table (I): Molar conductance and analytical data

\begin{tabular}{|l|c|c|c|}
\hline \multicolumn{1}{|c|}{ Compound } & M.P. ${ }^{\circ} \mathrm{C}$ & $\Lambda_{\mathrm{m}}(\mathrm{DMF})$ & M\% (found) \\
\hline HAOP & 150 & & \\
\hline $\mathrm{HAEA}$ & 140 & & \\
\hline $\mathrm{HAPA}$ & 135 & & $(9.56) 10.09$ \\
\hline$\left[\mathrm{Co}(\mathrm{HAOP})_{2}\right] \mathrm{Cl}_{2}$ & 180 & 155 & $(11.63) 10.06$ \\
\hline$\left[\mathrm{Ni}(\mathrm{HAOP})_{2}\right] \mathrm{Cl}_{2}$ & 162 & 160 & $(10.32) 11.07$ \\
\hline$\left[\mathrm{Cu}(\mathrm{HAOP})_{2}\right] \mathrm{Cl}_{2}$ & 176 & 135 & $(12.62) 12.93$ \\
\hline$\left[\mathrm{Zn}(\mathrm{HAOP})_{2}\right] \mathrm{Cl}_{2}$ & 182 & 140 & $(12.71) 12.83$ \\
\hline$\left[\mathrm{Co}(\mathrm{HAEA})_{2}\right] \mathrm{Cl}_{2}$ & 170 & 153 & $(12.92) 12.80$ \\
\hline$\left[\mathrm{Ni}(\mathrm{HAEA})_{2}\right] \mathrm{Cl}_{2}$ & 168 & 145 & $(13.82) 14.14$ \\
\hline$\left[\mathrm{Cu}(\mathrm{HAEA})_{2}\right] \mathrm{Cl}_{2}$ & 195 & 138 & $(13.10) 13.40$ \\
\hline$\left[\mathrm{Zn}(\mathrm{HAEA})_{2}\right] \mathrm{Cl}_{2}$ & 185 & 162 & $(13.13) 13.35$ \\
\hline$\left[\mathrm{Co}(\mathrm{HAPA}) \mathrm{Cl}_{2}\right]$ & 160 & 30 & $(13.85) 14.65$ \\
\hline$\left[\mathrm{Ni}(\mathrm{HAPA}) \mathrm{Cl}_{2}\right]$ & 170 & 17 & \\
\hline$\left[\mathrm{Cu}(\mathrm{HAPA}) \mathrm{Cl}_{2}\right]$ & 184 & 20 & 14.30 \\
\hline$\left[\mathrm{Zn}(\mathrm{HAPA}) \mathrm{Cl}_{2}\right]$ & 190 & 25 & \\
\hline
\end{tabular}

Characterization of the bonding sites of the ligand and the structure of the complexes were carried out by Infrared spectra, electronic spectra and magnetic susceptibility studies. 


\section{Infrared spectra}

The ligands show characteristic bands around 3450, 1635, 1300, $1210 \mathrm{~cm}^{-1}$ which are due to $v_{\mathrm{OH}}, v_{\mathrm{C}=\mathrm{N}}, \delta_{\mathrm{OH}}$ and $v_{\mathrm{C}-\mathrm{O}}$ respectively (Table II). For complexes formed, the $v_{\mathrm{OH}}, \delta_{\mathrm{OH}}$ and $v_{\mathrm{C}=\mathrm{N}}$ band are shifted to lower frequency values by about $100-130,20-30$, and $15-35 \mathrm{~cm}^{-1}$ respectively. These negative shifts suggest coordination through hydroxyl oxygen and azomethine nitrogen atoms. Further support to this coordination is the splitting of $v_{\mathrm{C}-\mathrm{O}}$ band into two peaks which due to $\mathrm{C}-\mathrm{O}$ bonding. For all complexes new bands were noticed around $(460-470),(425,430) \mathrm{cm}^{-1}$ are attributed to the stretching modes of M-O and M-N respectively [21].

\section{Electronic spectra and magnetic moments}

The position of electronic spectral bands and the effective magnetic moments values together are given in (Table III). For type I and III complexes the spectra of cobalt (II) complexes exhibit three bands due to the spin-allowed transitions ${ }^{4} \mathrm{~T} g(\mathrm{~F}) \longrightarrow{ }^{4} \mathrm{~T}_{2} \mathrm{~g}(\mathrm{~F}) v_{1},{ }^{4} \mathrm{~T} / \mathrm{g}(\mathrm{F}) \longrightarrow{ }^{4} \mathrm{~A}_{2} \mathrm{~g}(\mathrm{~F}) v_{2}$, ${ }^{4} \mathrm{~T}_{1} \mathrm{~g}(\mathrm{~F}) \longrightarrow{ }^{4} \mathrm{~T}_{1} \mathrm{~g}(\mathrm{p}) v_{3}$. The three bands in the spectra of nickel (II) complexes are corresponding to ${ }^{3} \mathrm{~A}_{2} \mathrm{~g}(\mathrm{~F}) \longrightarrow{ }^{3} \mathrm{~T}_{2} \mathrm{~g}(\mathrm{~F}) v_{1}$, ${ }^{3} \mathrm{~A}_{2} \mathrm{~g}(\mathrm{~F}) \longrightarrow{ }^{3} \mathrm{~T}_{1} \mathrm{~g}(\mathrm{~F}) v_{2},{ }^{3} \mathrm{~A}_{2} \mathrm{~g}(\mathrm{~F}) \longrightarrow{ }^{3} \mathrm{~T} \mathrm{~g}(\mathrm{P}) v_{3}$ transition. The number and positions of these bands corresponding to octahedral structure for both cobalt and nickel complexes [22,23]. The electronic spectra of the copper complexes show only one broad bands, since the location of this band below $15000 \mathrm{~cm}^{-1}$ there for octahedral structure is the most probable for this hexacoordination copper (II) complexes, the asymmetric band due to the combined transitions ${ }^{2} \mathrm{~B}_{1} \mathrm{~g} \longrightarrow{ }^{2} \mathrm{~A}_{1} \mathrm{~g},{ }^{2} \mathrm{~B}_{1} \mathrm{~g} \longrightarrow{ }^{2} \mathrm{~B}_{2} \mathrm{~g},{ }^{2} \mathrm{~B}_{1} \mathrm{~g} \longrightarrow{ }^{2} \mathrm{Eg}$.

On the other hands the electronic spectra for HAEA cobalt. Nickel and copper having tetrahedral geometry [22] and the bands are attributed to ${ }^{4} \mathrm{~A}_{2}(\mathrm{~F}) \longrightarrow{ }^{4} \mathrm{~T}_{2}(\mathrm{~F}) \quad, \quad{ }^{4} \mathrm{~A}_{2} \longrightarrow{ }^{4} \mathrm{~T}_{1}(\mathrm{~F}), \quad{ }^{4} \mathrm{~A}_{2}(\mathrm{~F}) \longrightarrow{ }^{4} \mathrm{~T}_{1}(\mathrm{P})$, ${ }^{3} \mathrm{~T}_{1}(\mathrm{~F}) \longrightarrow{ }^{3} \mathrm{~T}_{2}(\mathrm{~F}), \quad{ }^{3} \mathrm{~T}_{1}(\mathrm{~F}) \longrightarrow{ }^{3} \mathrm{~A}_{2}(\mathrm{~F}), \quad{ }^{3} \mathrm{~T}_{1}(\mathrm{~F}) \longrightarrow{ }^{3} \mathrm{~T}_{1}(\mathrm{P}) \quad$ and ${ }^{2} \mathrm{~T}_{2}(\mathrm{~F}) \longrightarrow{ }^{2} \mathrm{E}$ transition [24].

In the electronic spectra of the zinc (II) complexes, in addition to the broad band observed which due to $\pi \rightarrow \pi^{*}$ transition of the free ligand, new additional band was observed for complexes 37212-27297 $\mathrm{cm}^{-1}$, this new band may be attributed to charge transfer transition from filled orbitals of the ligand to the orbitals of the metal and thus supporting the formation of complexes some times the ligands are characterized by two observation bands in the UV. region. A high intensity band and second band with lower intensity both bands showed ared shift on coordination with zinc ion. These observation represent of other indication for the coordination of the ligand to zinc ion $[25,26]$. 
The magnetic susceptibility of the complexes was measured at room temperature by using the faraday method [27]. Magnetic moment measurements of the complexes correspond to the presence of three, two and one unpaired electrons for $\mathrm{Co}$ (II) $\mathrm{d}^{7}, \mathrm{Ni}$ (II) $\mathrm{d}^{8}$ and $\mathrm{Cu}$ (II) $\mathrm{d}^{9}$ species, respectively [28].

On the light of the above studies, its concluded that the ligands (HAOP, HAEA, HAPA) coordinating through hydroxyl and azomethine groups giving the most expected structures as show in fig (I), (II), (III).

Table (II): The most important I.R bands $\left(\mathrm{cm}^{-1}\right)$ of the ligands and their complexes

\begin{tabular}{|l|c|c|c|c|c|c|}
\hline Compound & $v_{\mathrm{OH}}$ & $v_{\mathrm{C}=\mathrm{N}}$ & $\delta_{\mathrm{OH}}$ & $v_{\mathrm{C}-\mathrm{O}}$ & $v_{\mathrm{M}-\mathrm{O}}$ & $v_{\mathrm{M}-\mathrm{N}}$ \\
\hline $\mathrm{HAOP}$ & 3410 & 1635 & 1280 & 1180 & - & - \\
\hline $\mathrm{HAEA}$ & 3450 & 1635 & 1300 & 1185 & - & - \\
\hline $\mathrm{HAPA}$ & 3420 & 1630 & 1300 & 1210 & - & - \\
\hline$\left[\mathrm{Co}(\mathrm{HAOP})_{2}\right] \mathrm{Cl}_{2}$ & 3300 & 1610 & 1250 & 1160 & 470 & 425 \\
\hline$\left[\mathrm{Ni}(\mathrm{HAOP})_{2}\right] \mathrm{Cl}_{2}$ & 3290 & 1610 & 1250 & 1160 & 460 & 425 \\
\hline$\left[\mathrm{Cu}(\mathrm{HAOP})_{2}\right] \mathrm{Cl}_{2}$ & 3295 & 1600 & 1255 & 1160 & 460 & 430 \\
\hline$\left[\mathrm{Zn}(\mathrm{HAOP})_{2}\right] \mathrm{Cl}_{2}$ & 3290 & 1600 & 1255 & 1160 & 465 & 420 \\
\hline$\left[\mathrm{Co}(\mathrm{HAEA})_{2}\right] \mathrm{Cl}_{2}$ & 3320 & 1610 & 1270 & 1195 & 460 & 430 \\
\hline$\left[\mathrm{Ni}(\mathrm{HAEA})_{2}\right] \mathrm{Cl}_{2}$ & 3290 & 1615 & 1270 & 1190 & 460 & 425 \\
\hline$\left[\mathrm{Cu}(\mathrm{HAEA})_{2}\right] \mathrm{Cl}_{2}$ & 3300 & 1610 & 1275 & 1190 & 470 & 430 \\
\hline$\left[\mathrm{Zn}(\mathrm{HAEA})_{2}\right] \mathrm{Cl}_{2}$ & 3295 & 1610 & 1275 & 1195 & 760 & 420 \\
\hline$\left[\mathrm{Co}(\mathrm{HAPA}) \mathrm{Cl}_{2}\right]$ & 3330 & 1615 & 1280 & 1165 & 470 & 430 \\
\hline$\left[\mathrm{Ni}(\mathrm{HAPA}) \mathrm{Cl}_{2}\right]$ & 3330 & 1610 & 1275 & 1160 & 465 & 420 \\
\hline$\left[\mathrm{Cu}(\mathrm{HAPA}) \mathrm{Cl}_{2}\right]$ & 3330 & 1610 & 1275 & 1165 & 465 & 425 \\
\hline$\left[\mathrm{Zn}(\mathrm{HAPA}) \mathrm{Cl}_{2}\right]$ & 3300 & 1615 & 1270 & 1165 & 470 & 430 \\
\hline
\end{tabular}

Table (III): Electronic spectral data and magnetic of the complexes

\begin{tabular}{|l|c|c|c|c|c|}
\hline \multirow{2}{*}{ Compound } & \multirow{2}{*}{$\mu_{\text {eff }}$ (B.M.) } & \multicolumn{3}{|c|}{ Electronic spectra } & \multirow{2}{*}{ C.T. } \\
\cline { 3 - 5 } & & $v_{1}$ & $v_{2}$ & $v_{3}$ & \\
\hline$\left[\mathrm{Co}(\mathrm{HAOP})_{2}\right] \mathrm{Cl}_{2}$ & 4.81 & 10123 & 14725 & 21436 & 28523 \\
\hline$\left[\mathrm{Ni}(\mathrm{HAOP})_{2}\right] \mathrm{Cl}_{2}$ & 3.20 & 10300 & 15661 & 24420 & 31813 \\
\hline$\left[\mathrm{Cu}(\mathrm{HAOP})_{2}\right] \mathrm{Cl}_{2}$ & 2.14 & 14401 & - & - & 24182 \\
\hline$\left[\mathrm{Zn}(\mathrm{HAOP})_{2}\right] \mathrm{Cl}_{2}$ & - & - & - & - & 27297, \\
\hline$\left[\mathrm{Co}(\mathrm{HAEA})_{2}\right] \mathrm{Cl}_{2}$ & 4.12 & - & - & 14375 & 30155 \\
\hline$\left[\mathrm{Ni}(\mathrm{HAEA})_{2}\right] \mathrm{Cl}_{2}$ & 3.64 & - & - & 13355 & 30611 \\
\hline$\left[\mathrm{Cu}(\mathrm{HAEA})_{2}\right] \mathrm{Cl}_{2}$ & 1.98 & 11733 & - & - & 31011 \\
\hline$\left[\mathrm{Zn}(\mathrm{HAEA})_{2}\right] \mathrm{Cl}_{2}$ & - & - & - & - & 28911, \\
\hline$\left[\mathrm{Co}(\mathrm{HAPA}) \mathrm{Cl}_{2}\right]$ & 4.83 & 10220 & 15435 & 121878 & 30751 \\
\hline$\left[\mathrm{Ni}(\mathrm{HAPA}) \mathrm{Cl}_{2}\right]$ & 3.17 & 10712 & 14175 & 25211 & 32815 \\
\hline$\left[\mathrm{Cu}(\mathrm{HAPA}) \mathrm{Cl}_{2}\right]$ & 2.03 & 14476 & - & - & 303211 \\
\hline$\left[\mathrm{Zn}(\mathrm{HAPA}) \mathrm{Cl}_{2}\right]$ & - & - & - & - & 30864, \\
\hline
\end{tabular}


Preparation, Charaterization and Study of Cobalt (II), Nickel (II), ...

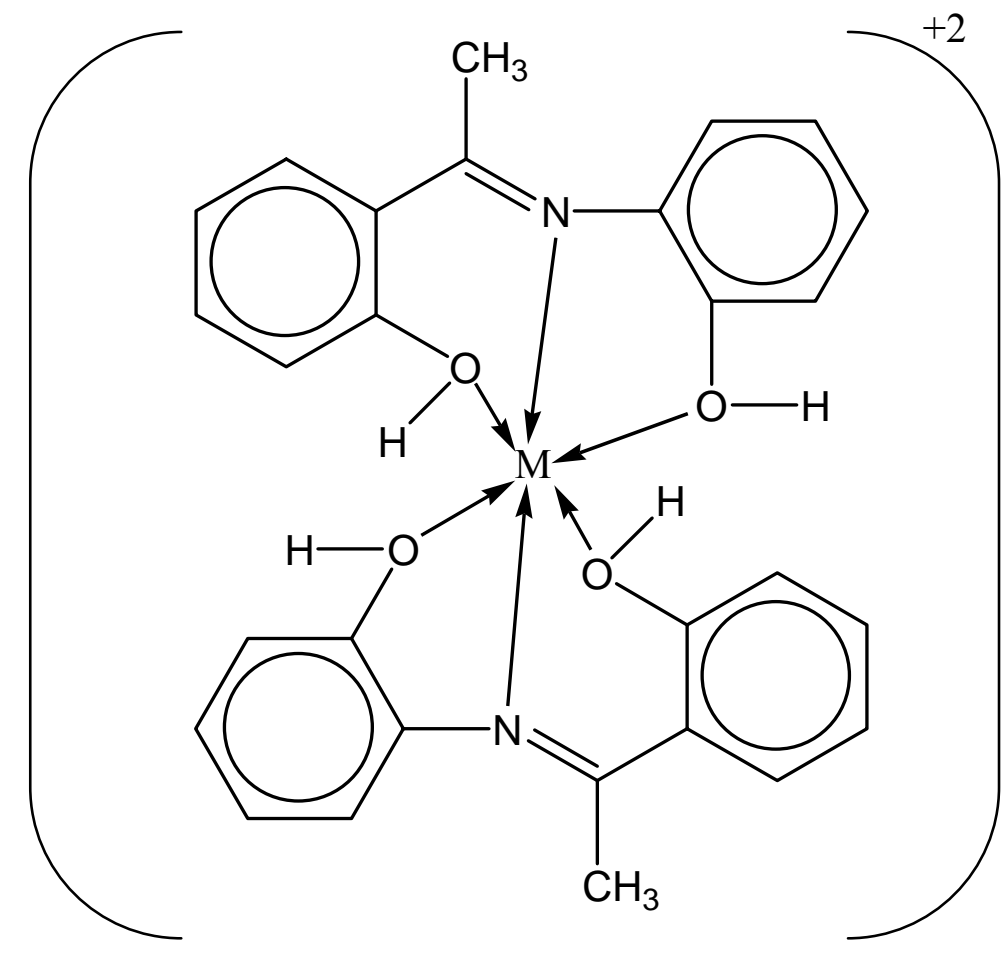

Fig (I)

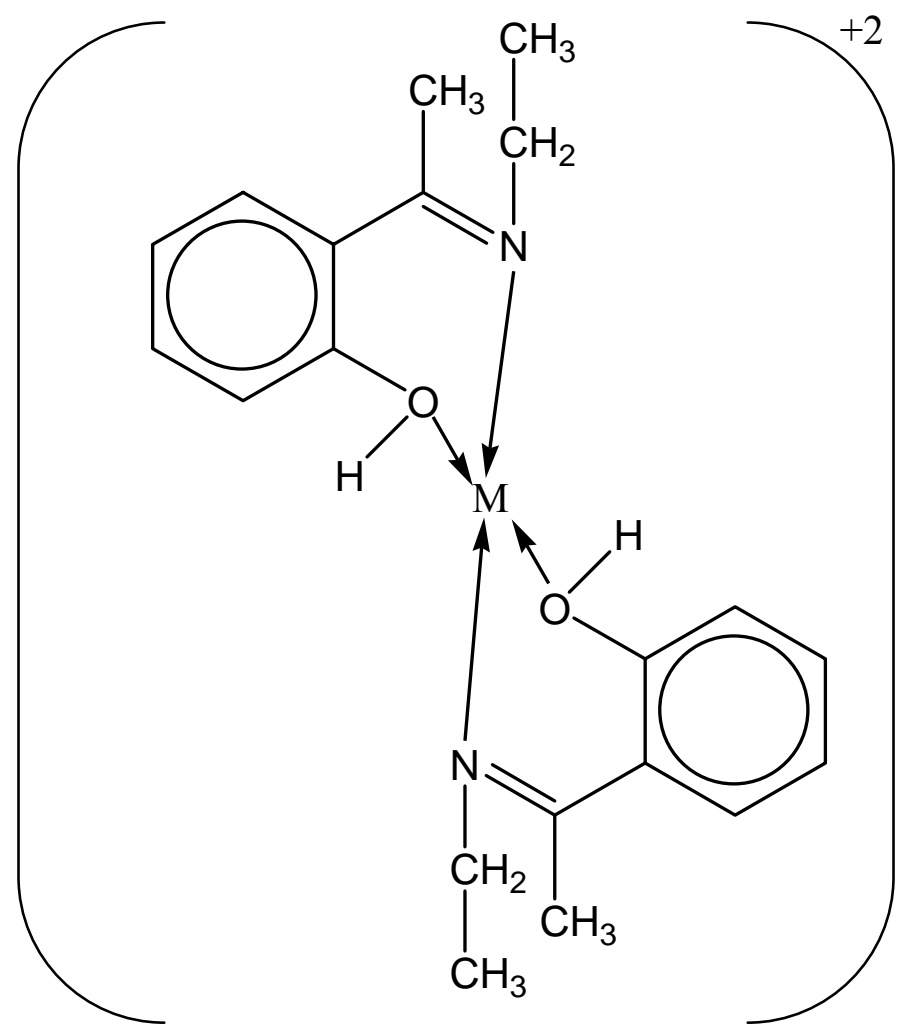

Fig (II) 


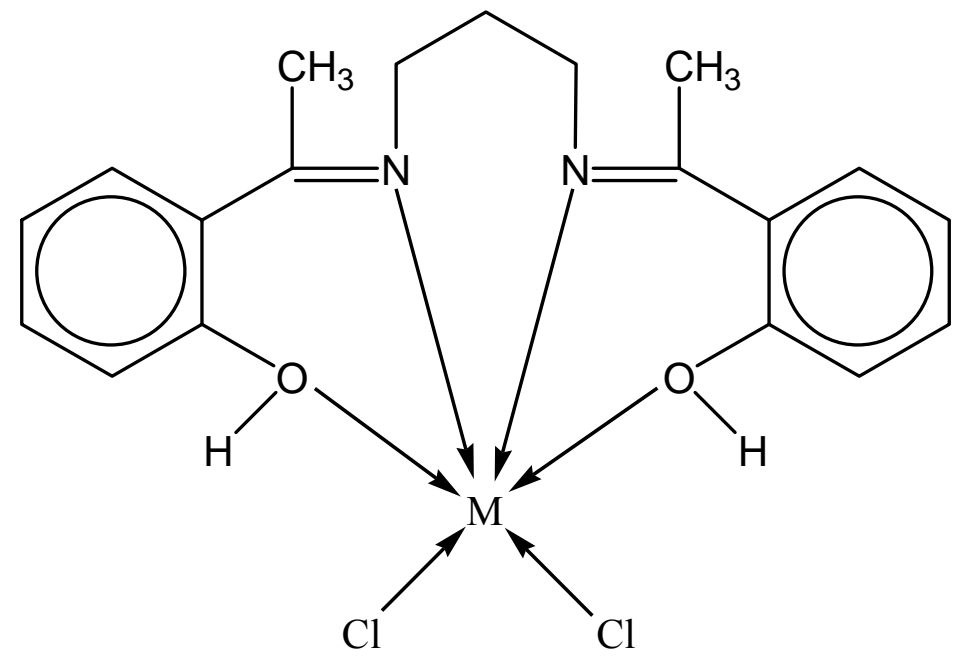

Fig (III)

$\mathrm{M}=\mathrm{Co}^{2+}, \mathrm{Ni}^{2+}, \mathrm{Cu}^{2+}, \mathrm{Zn}^{2+}$

\section{REFERENCE}

1) Sousa C., Freire C. and Decastro B., Molecules, 8, 894, (2003).

2) Singh V. K., Singh R. and Sinha B. K., Asian J. Chem., 110, 532, (1998).

3) Yildirm L. T. and Atakol O., Cryst. Res., Technol., 37, 1332, (2002).

4) Garnovski A. D. and Linivorozhkin A., Coord. Chem. Rev., 126, 1, (1993),

5) Pui A., Croatica Chemica Acta, 75, 165, (2002).

6) Hamiton D. E., Drago R. S. and Zombeck A., J. Am. Soc., 109, 374, (1987).

7) Chen D. and Martel A. E., Inorg. Chem., 26, 1026, (1987).

8) Costamagna J., Vargas J. and Menay G., Coord. Chem. Rev., 119, 67, (1992).

9) Bilman H. J. and Schrmidgall R. L., J. Pharm. Sci., 59, 119, (1970).

10) Shady H. F. A. and Aly E. L., Chem. Abs., 110, 1730, 68m, (1970).

11) Blackburn P. J., Buckingham R. E. and Chan W. M., Biol. Org med. Chem. lett., 5(11) 11636, (1996). 
12) Santos M. L. P., Bagatin I. A. and Pereina E. M., J. Chem. Soc., Dalton Trans., 838, (2001).

13) Martinez M. A. and Rosado R. C., J. Chem. Soc., Dalton Trans., 234, (2001).

14) Liu and Xiong C. M., Polyhedron, 15, 4565-4571, (1996).

15) Djebbar and Benali S. S., Transit. Metal. Chem., 23, 443-447, (1998).

16) Hamada Y. J., IEEE Trans. Electron Devices, 44, 1208-1217, (1997).

17) Yildirm L. T., Emregul K. C. and Atakol O., Cryst. Res. Technol., 37, 1344, (2002).

18) Bhawon G., Wah H. and Narain Z., Polyhedron, 18, 341, (1999).

19) Kessel S. L. and Emberson R. M., Inorg. Chem., 19, 1170, (1980).

20) Geory W. J., Coord. Chem. Rev., 81, 7, (1971).

21) Madan S. K. and Donohus A. M., J. Inorg. Nucl. Chem., 25, 1303, (1969).

22) Michael I. and Watton A., J. Inorg. Nucl. Chem., 37, 17, (1975).

23) Madan S. K. and Muellar D. I., J. Inorg. Nucl. Chem., 25, 177, (1966).

24) Perlepes S. P., Kabanos T. and Lazaridou V., Inorg. Chim Acta, 117, 27, (1986).

25) Kokamoto T. K. and Hidaka J., Inorg. Chem., 33, 538, (1994).

26) Parihri R. K., Patel R. K. and Patel R. N., Oriental, J. Chem., 15, 387, (1999).

27) Pass G. and Sutelfie H., "Practical Inorganic Chemistry", $2^{\text {nd }}$ ed., Chapman and Hall, (1974).

28) Cotton F. A. and Gwilkinson, "Advanced Inorganic Chemistry", $4^{\text {th }}$ ed., Wiley, New York, (1980). 